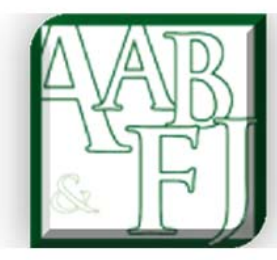

\title{
Editorial: AABFJ Volume 8, Issue 2
}

\section{Ciorstan Smark ${ }^{1}$}

This issue of AABFJ brings together diverse articles from the fields of finance, banking and accounting. Frino, He and Lepone (2014) examine the efficiency of the Treasury Bond futures market in Australia. They find a significant positive relationship between volatility and time to expiry on one hand and the absolute level of mispricing on the other. Lee, Chen and Tsai (2014) use a panel cointegration model to test the Ohlson model and find it to be a powerful predictor of future market value.

From banking, Deng and Liu (2014) examine how monetary policy changes flow through the Australian banking sector and find that the effect can depend on the size and type of the bank under consideration.

Huang, Pepper and Bowrey (2014) illustrate the use of a Sustainability Balanced Scorecard (SBSC) as a factor in organisational legitimacy assessment. Steen, Turpie and Ng (2014) examine the microcap side of mergers and acquisitions and finds differences between these microcap processes and those involving larger firms. Rusmin, Estami and Scully (2014) round out our issue with an examination of the outcomes of decentralisation reforms in local government in Indonesia.

Two technical notes are also included in this issue. Silva Guerreiro, Lima Rodrigues and Craig explore influences on unlisted companies when Portugal moved from a code law, rules-based accounting system, to a principles-based accounting system of adapted International Financial Reporting Standards (IFRS).Watts, Yapa and Dellaportas report on a case study involving a multinational manufacturing company implementing a new management accounting system.

On an organisational front, after eight years with AABFJ, I am interested in any expressions of interest in taking over the Editor in Chief role for three years beginning in late 2015. Please watch our website for more information in the next few months.

\footnotetext{
${ }^{1}$ University of Wollongong

Email: csmark@uow.edu.au
} 
AABFJ | Volume 8, no. 2, 2014 